LINDA HAMILTON KRIEGER

\title{
The Burdens of Equality: Burdens of Proof and Presumptions in Indian and American Civil Rights Law
}

\section{INTRODUCTION}

In attempting to understand the relationship between law and the larger society of which it is a part, it is useful to distinguish between laws used to enforce traditional social norms and laws enacted to displace or transform them. Laws function quite differently, and threats to their effective mobilization and enforcement vary significantly, in each of these socio-legal contexts.

Modern Indian legal history provides numerous examples of the formal displacement of traditional norms by new legal rules. Indeed, as Marc Galanter has observed, ${ }^{1}$ modern Indian legal history provides a salient example of the broad based formal displacement of an entire indigenous legal order by what he refers to as modern law.

However as Galanter also notes, in the Indian context as in others one must not confuse formal displacement with actual transformation. Even after modern law has displaced traditional norms within a formal legal system, the traditional norms persist in the larger society, and stand poised to "interpret, adjust, take over, manipulate, change, and/or possess the new modern system."2

It may be useful then to distinguish between three categories or classes of law: law which corresponds to and seeks to enforce traditional norms; law which seeks to displace or transform traditional norms; and law which, although originally intended to displace traditional norms, has been coopted in the manner Galanter describes. For ease of description, we might refer to these three categories respectively as "normal law," "transformative law," and "captured law."

Instances of transformative law, that is, instances in which traditional norms have been at least formally supplanted by new legal rules, can be expected to emerge in a variety of socio-political

* Linda Hamilton Krieger is an Acting Professor of Law at the University of California at Berkeley, School of Law (Boalt Hall). B.A. Stanford University, 1975;

J.D. New York University, 1978.

1. Marc Galanter, Law and Society in Modern India (1989).

2. Id. at 15 . 
contexts. First, as occurred in nineteenth century India, transformative law may emerge from colonial conditions. In this context, the colonizing society, often with the help of indigenous collaborators, imposes laws and/or legal procedures expressing norms congenial to the colonizers but remote from the indigenous culture.

Transformative law can also emerge from federal political arrangements, in which majoritarian social norms differ in the various constituent states. In these situations, federal law may express norms congenial to a majority of the constituent states, but inconsistent with traditional norms in one or more of them. Although the federal majority tends not to see it this way, federal law in this context functions much like colonial law, formally displacing traditional local norms, which persist outside of the formal legal field and resist or seek to coopt it.

Finally, transformative law can emerge from any intellectually, culturally, or politically pluralistic society, in which, through judicial, executive, or legislative action, a distinct class or interest group succeeds in enacting reformist laws aimed at displacing popular norms which that class or interest group perceives as unjust. Civil rights laws and laws designed otherwise to assist or uplift traditionally subordinated groups often emerge in this way, as one among many species of transformative law.

As earlier noted, the formal displacement of traditional norms by new legal rules does not guarantee their de facto displacement in the relevant socio-legal environment. Through a variety of mechanisms, traditional norms resist displacement by the new legal rules.

Consider, for example, the threats posed by traditional normative systems to the effective enforcement of transformative laws designed to protect or uplift historically subordinated groups. In the case of criminal laws, or civil laws as to which there exists no private right of action, law enforcement officials, whose personal loyalties frequently lie with the traditional normative system, may be unwilling to enforce the new legal rules at the expense of traditional norms. Where a victim complaint is required to initiate formal legal proceedings, social pressures, expressed as either subtle or blatant social boycotts or reprisals, may make resort to the new legal protections by their intended beneficiaries too costly. Similar social pressures may constrain the willingness of witnesses to cooperate with the new legal order, resulting in the suppression of evidence needed to make successful enforcement even remotely possible.

Judges, whose conscious or unconscious allegiance often lies with traditional rather than transformative legal norms, may also constrain the new law's effective implementation. Administrative officials functioning in a quasi-judicial capacity, along with both trial and appellate level judges, can exploit loopholes or ambiguities in the 
law, thereby systematically limiting its practical sphere of application. Or, as legal sociologist Lauren Edelman has described, ${ }^{3}$ traditional norms may so thoroughly influence the elaboration and interpretation of the new legal rules that those new legal norms actually end up providing a vehicle for the reassertion and relegitimation of the traditional normative regime. In this way, transformative law becomes captured law.

The operation of subtle cognitive and motivational biases which distort social perception and judgment may further constrain the implementation of transformative law. The mechanisms by which social stereotypes, social group allegiances, and subjective conceptions of justice or fairness bias the evaluation of evidence in civil and criminal adjudication are well-documented in the social psychological literature. ${ }^{4}$ Either deliberately, or as a consequence of unconscious biases in the evaluation of ambiguous information, lay jurors or judges acting as fact-finders may be reluctant to draw the inferences required to support a finding of guilt or civil liability under the new legal rules.

Finally, and often in combination with the above-described phenomena, implementation of transformative law may be constrained by resource imbalances between prosecution and defense. In the context of "normal" criminal law, where prosecutors act to enforce dominant social norms, they are likely to occupy positions of greater power and to possess greater resources than the strata of defendants they prosecute. However, where transformative law challenges or seeks to displace traditional norms, the opposite condition will often obtain. At least in the civil rights context, transformative law is most frequently mobilized by social "outsiders" against social "insiders." As a general rule, social insiders have greater access to legal resources than do social outsiders. Thus, where transformative laws are criminal rather than civil in nature, state actors frequently find themselves prosecuting individuals who occupy a significantly higher economic and social station and command far greater popular support than characterizes the strata of defendants most commonly prosecuted for violations of normal law. These relatively well-resourced defendants are better able than their normal law counterparts to exploit the law's soft-spots, and thereby restrict its application, either to them individually, or more broadly as a function of judicial precedent.

There are then, I would argue, significant differences between normal and transformative law. They serve fundamentally different

3. Edelman, Lande, \& Erlanger, "Internal Dispute Resolution: The Transformation of Civil Rights in the Workplace," 27 Law and Society Review 497 (1992).

4. For a review of these literatures, see, e.g., Tom R. Tyler, Robert J. Boeckmann, Heather J. Smith \& Yuen J. Huo, Social Justice in a Diverse Society 53 54 (1997); Armour, "Stereotypes and Prejudice: Helping Legal Decisionmakers Break the Prejudice Habit," 83 Cal. L. Rev. 733 (1995); Moore, "Trial by Schema: Cognitive Filters in the Courtroom," 37 U.C.L.A. L. Rev. 273 (1989). 
social purposes and are subject to different forms of abuse. Sources of threat to their effective enforcement can be expected to vary considerably, in both nature and degree. Evidentiary or procedural rules which perform defined policy functions in the context of one may work profoundly different results in the other. Correspondingly, the absence of a particular process protection may occasion little difficulty in one context, while resulting in profoundly negative consequences in the other. In short, procedural and evidentiary devices designed with normal law in mind may function quite differently where transformative law is concerned.

My purpose here is to examine two such procedural/evidentiary devices - the burden of proof, and its close relative, the evidentiary presumption - and to compare how these function in one American and three Indian civil rights statutes. On the Indian side, I explore the Protection of Civil Rights Act, 1955,5 the Dowry Prohibition (Amendment) Act, 1986, and the Criminal Law (Second Amendment) Act of 1983. I compare these, and in particular, their allocation of burdens of proof, with the quite different allocation regime contained in the most frequently mobilized U.S. civil rights statute, Title VII of the Civil Rights Act of 1964.

All of these statutes, at least when first enacted, could fairly be described as instances of transformative law. All represent federal law, imposed on at least some states which, at the time the laws were enacted, would not have enacted them themselves. All were championed by a coalition of socio-cultural groups within the larger society in an effort to displace deeply entrenched traditional norms which those responsible for the laws' passage found objectionable on moral and philosophical grounds. Through all of the mechanisms described above, both sets of laws have been resisted by at least significant portions of the communities on which they were imposed.

One salient difference between these two sets of laws provides the subject for our present inquiry. As will be described in more detail below, all three of the Indian statutes I examine, like many other instances of transformative Indian law, attempt to use presumptions and burdens of proof as a tool for countering the traditional normative system's resistance to the implementation of the new legal regime. As it has been interpreted by American courts, Title VII does not.

My present inquiry centers on the following questions. What can we learn about the role of burdens of proof and presumptions in transformative legal regimes by comparing how these are allocated

5. Enacted in 1955 , the Act was originally entitled "The Untouchability (Offences) Act of 1955." It was amended in 1976 by the Untouchability (Offences) Amendment and Miscellaneous Provisions Act, at which time its title was changed to the Protection of Civil Rights Act. 
and defined in Indian and American civil rights law? How can the Indian experience inform American law, and in particular, current controversies over the proper allocation of burdens of proof in certain categories of civil rights cases? How might the American experience alert the Indian legal community to the questions and conflicts that likely lie ahead, as its civil rights laws develop and come to be more frequently and effectively mobilized by beneficiary groups? And, more broadly, how closely does existing thought about the policy functions served by burdens of proof and presumptions map onto the comparative Indian/American civil rights experience?

\section{Burdens of Proof and Presumptions in Transformative Indian Law}

\section{A. The Protection of Civil Rights Act}

The institution of Untouchability is rooted in Hindu culture and religion. It derives from the systems of varnas, or castes, into which Indian society was theoretically divided in traditional Hindu law. ${ }^{6}$ Three of the four varnas, the Brahmin, the Kshatriya, and the Vaishya, command the highest ritual standing. Members of these three varnas, by virtue of their investment with the "sacred thread," were regarded as "twice born." The fourth varna, the Shudra, was considered socially inferior to the other three. Persons falling outside of these four groups, or in some regions, persons in or at the bottom of the Shudra caste, were considered ritually impure and were subject to severe social and political disabilities. Individuals falling into these categories and treated in this manner came to be known as "Untouchables."

While the disabilities enforced against so-called Untouchables, and the precise composition of the groups on which they were imposed, varied from region to region, those disabilities tended to include: denial of access to public facilities such as wells, bathing facilities, schools, roads, post offices, and courts; denial of access to temples and other sacred places, including places of religious learning; exclusion from large classes of employment and educational opportunities; segregation into the most menial, dirty occupations; residential segregation; and denial of access to private shops and services.

6. Throughout this short treatment of Untouchability in Indian society, I will spare the reader detailed footnotes. References used in constructing this overview include S.K. Aswathi, The Scheduled Castes and Scheduled Tribes (Prevention of Atrocities) Act, 1989 (1992); Marc Galanter, Law and Society in Modern India (1989); Marc Galanter, Competing Equalities: Law and the Backward Classes in India (1984); J. Michael Mahar, (ed.), The Untouchables in Contemporary India (1972); and M. N. Srinivas, Caste in Modern India and Other Essays (1966). 
During the period of colonial rule, the British made no active effort to eliminate the caste system, although the establishment of a colonial legal order which failed to institutionalize caste distinctions necessarily destabilized them to some extent. In the absence of official government action to enforce caste distinctions, private actors systematically engaged in "self-help," in the form of boycotts and reprisals, to enforce traditional caste disabilities.

Untouchability came under intense indigenous attack during the Indian Independence Movement. Mohandas Gandhi vigorously decried the injustice worked by the institution of Untouchability, and called for a purified varnashrama dharma, in which the Untouchables would be reabsorbed into the Shudra. Bimrao Amedkar, an Untouchable himself and the architect of what would become the Indian Constitution, advocated the abolition of the varna system in its entirety.

After Independence, the institution of Untouchability was formally eliminated by the Indian Constitution of 1950. Although numerous provisions are implicated in its disestablishment, the most directly applicable is found in Article 17, which provides:

"Untouchability" is abolished and its practice in any form is forbidden. The enforcement of any disability arising out of "Untouchability" shall be an offence punishable in accordance with law.

This provision, like other anti-discrimination provisions of the Indian Constitution, prohibits the enforcement of civil disabilities not only by the state, but by private actors as well.

This Constitutional prohibition was soon reinforced by the Untouchability (Offences) Act (UOA) of 1955. The Act as originally passed prohibited the imposition of disabilities on the ground of Untouchability in the provision of professional or commercial services, the right to practice a particular trade or occupation, or to use particular utensils, or in access to public accommodations, water, resources, charitable benefits, hospital or other health services, educational opportunities, housing, or places of worship. Discrimination in employment was added as a prohibited practice by amendment in $1976 .{ }^{7}$ Untouchability, although not actually defined in the Act, is generally interpreted as referring either to membership in a Scheduled Caste, as defined in Clause 24 of Article 366 of the Indian Constitution, or membership in any other group which by local custom or usage is regarded as "Untouchable."

The Untouchability (Offences) Act, renamed the Protection of Civil Rights Act by the 1976 amendments, is a criminal statute. Pen-

7. The Untouchability (Offences) Amendment and Miscellaneous Provision Act, 1976 (No. 106 of 1976), Anand Mohan Suri, (ed.), The Current Indian Statutes, 1955 (January - December), 836-44. 
alties for its violation include imprisonment for a term of one to six months; fines between one hundred and five hundred rupees, the cancellation or suspension of professional or trade licensing, and/or the suspension or revocation of government funding grants.

That aspect of the Act most relevant to our present inquiry is found in Sections 12, which provides:

Presumption by courts in certain cases. - Where any act constituting and offence under this Act is committed in relation to a member of a Scheduled Caste as defined in clause (24) of article 366 of the Constitution, the court shall presume, unless the contrary is proved, that such act was committed on the ground of "untouchability."

Thus, under Section 12, once the prosecution succeeds in proving that an act which, assuming requisite culpable intent, would constitute an offence when committed in relation to a member of a scheduled caste, the court is obliged to presume, until the contrary is proven by the defendant, that the act was committed on the ground of untouchability.

That the phrase "shall presume" signals a shift of the burden of persuasion on the issue of "grounds" to the defendant, and not merely a burden of coming forward with evidence, becomes clear by reference to the definition of that phrase in Section 4 of the Indian Evidence Act and to its interpretation by the Indian Supreme Court. Section 4 of the Indian Evidence Act provides, in relevant part:

S. 4. "MAY PRESUME". - Whenever it is provided by this [Act] that the Court may presume a fact, it may either regard such fact as proved, unless and until it is disproved, or may call for proof of it:

"ShAll PRESUME". - Whenever it is directed by this [Act] that the Court shall presume a fact, it shall regard such fact as proved, unless and until it is disproved. . .

Presumptions of the first type are referred to as "presumptions of fact," those of the second, "presumptions of law."

Under Indian law, these two types of presumptions have distinctly different effects. As the Indian Supreme Court noted in Syad Akbar v. State of Karnataka, "presumptions of fact merely affect the burden of going forward with the evidence. Presumptions of law,

8. M.C. Sarkar, S.C. Sarkar, \& Proabhas C. Sarkar, 1 Sarkar's Law of Evidence $66\left(13^{\text {th }}\right.$ ed. 1993). While the definitions of "may presume" and "shall presume" contained in Section 4 refer to the use of those terms in the Indian Evidence Act, the terms are accorded the same meaning elsewhere in Indian law, including in the Protection of Civil Rights Act. See, S. K. Awasthi, The Scheduled Castes and the Scheduled Tribes (Prevention of Atrocities) Act, 1989, 320 (1992 ed.), (defining the terms "shall presume" as used in Section 12 of the Protection of Civil Rights Act as it is defined in Section 4 of the Indian Evidence Act). 
however, go so far as to shift the legal burden of persuasion so that, in the absence of evidence sufficient to rebut it on a balance of probability, a verdict must be directed."9

In the language of American evidence law, the Indian presumption of fact functions somewhat like a Thayer "bursting bubble" presumption, as institutionalized by Federal Rule of Evidence 301. A presumption of fact, like a Rule 301 presumption, merely shifts the burden of producing evidence to the party against whom the presumption is raised. Assuming that evidence is produced, the ultimate burden of persuasion on the issue remains with the party upon whom it was originally placed. An Indian presumption of law, on the other hand, functions more like an American "Morgan presumption," shifting the burden of persuasion on the relevant element of liability, not only the burden of producing evidence, to the party against whom the presumption has been raised. ${ }^{10}$ Accordingly, in a case brought under the Protection of Civil Rights Act, once the prosecution has demonstrated that the complainant is a member of a Scheduled Caste, and that conduct specified in the Act was directed at such member of a Scheduled Caste, the burden of persuasion shifts to the defendant to prove, by a preponderance of the evidence, that the conduct was not taken "on the grounds of untouchability."11

\section{B. The Dowry Prohibition (Amendment) Act and the Criminal Law (Second Amendment) Act}

The common misconception that the practice of dowry is deeply rooted in Hindu law stems from a confusion between the practice of dowry and the traditional gifting practices of varadakshina and stridhan. Under traditional Hindu law, an approved marriage between two Hindus was considered a kanyadan. ${ }^{12}$ The Dharmashastra provided that the act of kanyadan was not complete until the bridegroom was given a dakshina, or gift, from the bride's father. Gifts were given to the bride as well, and these, referred to as stridhan, became her separate property to own and dispense with during marriage as she saw fit. ${ }^{13}$

9. AIR 1979 S.C. 1848 (1979 Cri. L. J. 1374).

10. For a discussion of the Morgan/Thayer debate and its resolution in Federal Rule of Evidence 301, see Charles Alan Wright \& Kenneth W. Graham, Jr., Federal Practice and Procedure: Evidence, Vol. 21, \$5122, 552-73.

11. See generally, S. K. Aswathi, supra n. 8, at 320 . Offenses charged under Section 7 of the P.O.C.R.A., involving the offering of "insult" to a member of a Scheduled Caste, appear to be analyzed somewhat differently. At least one court has held that, in "insult" cases, before the burden of persuasion shifts to the defendant the prosecution must also prove that the insult was "of a species" that had a "nexus" with untouchability. Laxman Jayaram v. State of Maharashtra, 1981 Cr L J 387 (Bombay).

12. Kanyadan is best translated into English as a kind of "sacrament," although the Hebrew word mitzvah probably captures its meaning more closely.

13. See, Report of the Joint Committee of the Houses to Examine the Question of the Working of the Dowry Prohibition Act, 1961, in Paras Diwan \& Peeyushi Diwan, 
The precise circumstances bridging between these traditions and the modern practice of dowry are contested and unclear. ${ }^{14}$ However the transition occurred, by the nineteenth century, the gifts previously associated with the marriage ceremony had lost their voluntary character and become obligatory on the bride's family.

During the twentieth century, the practice of dowry spread into geographical areas and religious communities where it had not previously been practiced. As the practice spread and intensified, husbands' families, who possessed greater bargaining power in relation to dowry for a variety of reasons, demanded increasingly large sums. Over time, a variety of extortionist tactics developed by which husbands' families extracted additional dowry during the course of the marriage. Perceptions that the bride's family had provided insufficient dowry, or failures of the bride's family to accede to repeated dowry requests, often led to harassment, physical violence, ejection from the husband's house, and even death - often by burning, or by "assisted suicide" - of the hapless, isolated wife. ${ }^{15}$

Perceptions that the practice of dowry had become a social evil of dramatic severity and scale led to the enactment by the Indian Parliament of the Dowry Prohibition Act of 1961. The Act represented the first national effort to prohibit the practice of dowry but was flawed in a number of significant respects. As a consequence, it proved relatively ineffective in either suppressing the practice of dowry, lessening the incidence of dowry-related violence, or providing a vehicle for the successful prosecution of dowry-demand or dowry violence-related offenses. ${ }^{16}$

Perhaps the most shocking of the social ills associated with the practice of dowry was a phenomenon that came to be known as "bride burning" or "dowry death." During the 1960's and 1970's, India experienced a dramatic increase in the number of incidents in which a married woman died in highly suspicious circumstances, but in which homicide could not be proved. Typically in these cases, the victim was a young woman, recently married, whose family had prior to her death been harassed by repeated demands for dowry. Frequently death was by suicide, or by burning, which the husband's family generally attributed to an accidental kitchen fire. Whether by staged "accident" or by suicide, the victim often died after months or years of

Dowry and Protection to Married Women, Appendix IV (3 $3^{\text {rd }}$ ed. 1995); Jethmalani \& Dey, "Dowry Deaths and Access to Justice," in Rani Jethmalani, (ed.), Kali's Yug: Empowerment, Law and Dowry Death 38-39 (1995).

14. For one historical explanation, see, Anshu Nangia, "The Tragedy of Bride Burning In India: How Should the Law Address It?," 22 Brook. J. Int'l L. 637, 641-43 (1997).

15. Report of the Joint Committee, supra n. 13, at 326-29; Nangia, id. at 644-46.

16. For a detailed discussion of the inadequacies of the Dowry Prohibition Act of 1961, see, Report of the Joint Committee, supra n. 13, at 330-39; Diwan \& Diwan, supra n. 13 , at 21 . 
physical and psychological cruelty, inflicted by her husband or members of the husband's family with whom the victim had lived, often in total social isolation from outsiders, including members of her own natal family. By the late 1970's, this phenomenon, now the subject of a high-profile social crusade by Indian feminists, came to be known as "dowry death," or "bride burning." 17

For a variety of reasons, Indian law proved inadequate to reckon with dowry-related violence. As of the early 1980's, India had no systematic legal framework for dealing with the problem of domestic abuse. And while the Indian Penal Code did criminalize homicide ${ }^{18}$ and abetment of suicide, ${ }^{19}$ prosecutions under these provisions in dowry death cases were, for a variety of reasons, rarely successful.

Prosecutors in these cases were generally able to prove the cause of death, and the fact that within a certain period of time before the victim's death, her family had been subject to one or more demands for dowry. But prosecutors were almost never able to prove that the death resulted from homicide rather than from accident, or by abetted suicide rather than by simple suicide, because the acts resulting in death almost always occurred within the husband's house, out of view of all but the husband and his family, who were often complicit in the crime and, in any event, virtually never provided testimony against their kin. ${ }^{20}$

Between 1983 and 1986, the Indian Parliament responded with a series of new laws designed to strengthen prosecutors' hand in responding to dowry-related offenses, including dowry deaths. Two of these, the Dowry Prohibition (Amendment) Act and the Criminal Law (Second Amendment) Act, are relevant to our present inquiry.

The Criminal Law (Second Amendment) Act of 1983, codified in part as Section 498-A of the Indian Penal Code, establishes criminal penalties for the infliction of physical or mental "cruelty" inflicted on a wife by her husband or in-laws. The statute provides in relevant part:

SECTION 498-A. Husband or relative of husband of a woman subjecting her to cruelty: Whoever, being the husband or the relative of the husband of a woman subjects such woman to cruelty, shall be punished with imprisonment for a term which may extend to three years and shall also be liable to fine.

Explanation - For the purpose of this section, "cruelty" means -

17. Vijayrao Mohite \& Vandana Chavan, Law of Cruelty, Abetment of Suicide and Dowry Deaths 226-27 (1993); D. N. Sandanshiv \& Jolly Mathew, "Legal Reform in Dowry Laws," in Rani Jethmalani, Kali's Yug, supra n. 13, at 80-81.

18. Indian Penal Code Section 302.

19. Indian Penal Code Section 306.

20. V. Mohite \& V. Chavan, supra n. 17, at 201-02, 226-27. 
(a) any willful conduct which is of such a nature as is likely to drive the woman to commit suicide or to cause grave injury or danger to life, limb or health (whether mental or physical) of the woman; or

(b) harassment of the woman where such harassment is with a view to coercing her or any person related to her to meet any unlawful demand for any property or valuable security, or is on account of failure by her or any person related to her to meet such demand. ${ }^{21}$

Under Section 498-A, subsection (b), harassment of a woman in connection with the making of demands for dowry is defined as a form of cruelty, chargeable under the statute. The definition set forth in subsection (a) is unrelated to dowry demands. Accordingly, violations of Section 498-A sometimes do and sometimes do not constitute dowryrelated offenses.

The 1983 law also included provisions designed to strengthen prosecutors' hand in dealing with abetment of suicide cases related both to the practice of dowry and to other forms of domestic abuse. Specifically, the statute added a new Section 113-A to the Indian Evidence Act of 1862 . That section, which will be discussed in greater detail below, provides:

S. 113-A. Presumption as to abetment of Suicide by A MARRIED WOMAN. - When the question is whether the commission of suicide by a woman had been abetted by her husband or any relative of her husband and it is shown that she had committed suicide within a period of seven years from the date of her marriage and that her husband or such relative of her husband had subjected her to cruelty, the Court may presume, having regard to all the other circumstances of the case, that such suicide had been abetted by her husband or by such relative of her husband. ${ }^{22}$

Although the precise operation of the presumption established by Section 113-A remains unclear, at a minimum it permits a court to infer from the facts of suicide during the first seven years of marriage and the infliction of cruelty upon the wife by her husband or in-laws, that the suicide was abetted by the husband, or by a member of his family, within the meaning of Indian Penal Code Section 306. As we will shortly see however, it does not necessarily operate to shift the burden of persuasion.

21. The Criminal Law (Second Amendment) Act, 1984 (Act No. 46 of 1983), V. Mohite \& V. Chavan, supra n. 17, at 74.

22. M. C. Sarkar, S. C. Sarkar, \& Prabhas C. Sarkar, 2 Sarkar's Law of Evidence $\left(13^{\text {th }}\right.$ ed., 1993) at 1501. 
Three years later, the Indian Parliament passed the Dowry Prohibition (Amendment) Act of 1986. Two provisions of this Act are also relevant to our present inquiry.

First, the Act amended the Indian Penal Code, adding a new Section 304-B, which established and defined the new crime of dowry death. That section provides, in relevant part:

S. 304-B. Dowry DeATH. - (1) Where the death of a woman is caused by any burns or bodily injury or occurs otherwise than under normal circumstances within seven years of her marriage and it is shown that soon before her death she was subjected to cruelty or harassment by her husband or any relative of her husband, for, or in connection with any demand for dowry, such shall be called "dowry death," and such husband or relative shall be deemed to have caused her death.

Simultaneously, Parliament amended the Indian Evidence Act, adding a new section 113-B, which established certain presumptions, and thereby allocated burdens of persuasion in prosecutions under Section 304-B. Section 113-B provides:

S. 113-B. Presumptions as to Dowry Death. - When the question is whether a person has committed the dowry death of a woman and it is shown that soon before her death such woman had been subjected by such person to cruelty or harassment for, or in connection with, any demand for dowry, the Court shall presume that such person had caused the dowry death. ${ }^{23}$

Under these two statutes, burdens of proof in dowry death prosecutions are allocated in the following way. First, the prosecution bears the burden of proving: (1) the death; (2) by burns, bodily injury, or other unnatural causes; (3) of a woman during her first seven years of marriage; and (4) the subjection of the woman to cruelty or harassment for, or in connection with, a demand for dowry; (5) soon before her death. ${ }^{24}$ Once these elements are proven by the prosecution beyond a reasonable doubt, a legal presumption is raised, and the burden of persuasion shifts to the defendant to prove, by a preponderance of the evidence, that he or she did not cause the victim's death. ${ }^{25}$ Thus, under this statute, as under the Protection of Civil Rights Act, once the prosecution has established certain facts predicate, the burden of persuasion shifts to the defendant to establish

23. Id., n. 20 at 1501 .

24. Obviously, the precise meaning of the various essential elements of the crime of dowry death, such as the meaning of "unnatural causes" or "soon before her death," are ambiguous and therefore subject to judicial interpretation. However, an exploration of how Indian courts have interpreted these concepts is beyond the scope of my present investigation.

25. V. Mohite \& V. Chavan, supra n. 17, at 197. 
that one of the essential elements of the crime is missing. In dowry death prosecutions, that element is causation in fact; in prosecutions under the Protection of Civil Rights Act, it is intent to discriminate on the grounds of untouchability.

Dowry-related suicides may be prosecuted either as abetment of suicide, under I.P.C. Section 306, or as dowry deaths, under Section 304-B. ${ }^{26}$ If prosecuted under the former statute, the presumption of fact established by Indian Evidence Act (I.E.A.) Section 113-A will apply. If prosecuted under the latter, the presumption of law under Section 113-B will attach, and along with it, an automatic shift to the defendant of the burden of persuasion on the issue of causation.

In attempting to understand the relationship between presumptions and burdens of proof in these statutes and under Indian law more generally, it is instructive to compare Sections 113-A and 113B. As indicated above, Section 113-A provides that, upon the establishment of certain facts by the state in an abetment of suicide prosecution, a court may presume that the defendant abetted the victim's suicide. Thus, in a prosecution for abetment of suicide under Indian Penal Code Section 306, once the prosecution establishes that the suicide occurred during the first seven years of marriage and that, prior to her suicide, the victim's husband or his relatives had subjected her to cruelty within the meaning of I.P.C Section 498-A, a presumption of some sort is raised. But precisely what kind of presumption is it?

The use of the phrase "may presume" in section 113-A signifies the presence of a Section 4 presumption of fact. As one influential commentary describes the matter, presumptions of this kind reflect "those natural inferences which the 'common course of natural events,' human conduct, and public and private business suggest to us." 27 Once a presumption of fact is raised, a court may on that basis alone regard the fact as proved, or may call for further proof of it."28 In this respect, it is "permissive, optional and discretionary."29

Presumptions of fact, reflecting the assumed "common course of natural events," are quite common in Indian law. Under Section 114 of the Indian Evidence Code, for example, a court may presume that a person in possession of stolen goods soon after their theft is either the thief or has received the goods knowing them to be stolen. A court may presume that evidence which could be and is not produced would, if produced, be unfavorable to the person who withholds it, or

26. Public Prosecutor, Andhra Pradesh High Court v. T. Punniah, 1989 Crl. L. J. 2330. See generally, Kali's Jug, supra n. 13, at 85 (Dowry-related suicide chargeable under I.P.C. Section 304-B as dowry death).

27. M.C. Sarkar, S. C. Sarkar, \& Prabhas C. Sarkar, 1 Sarkar's Law of Evidence, supra n. 8, at 67.

28. Indian Evidence Act, Section 4; V. Mohite \& V. Chavan, supra n. 17, at 192.

29. Id. 
that the common course of business had been followed in a particular case. ${ }^{30}$

Although one might reasonably assume from these examples that the presumption of fact operates in the same way as an inference operates under American law, this is not in fact the case. The distinction is explained as follows: "A presumption and an inference are not the same thing. A 'presumption' is a deduction which the law requires a trier to make; an 'inference' is a deduction which the trier of fact may or may not make according to his own conclusions. A presumption is mandatory; an inference is permissible." 31

Thus, a presumption of fact requires a court, in the absence of evidence to the contrary, to draw the conclusion specified in the statute. But, if evidence to the contrary is presented, the presumption does not compel a particular result. It is permissive in this respect. The function served by the presumption of fact is this: it compels a party who might otherwise remain silent to speak. If the party against whom the presumption is raised wishes not to have the point decided against him, he must come forward with evidence. He must take a stand. He must participate in the sharpening of the factual issue for the court's decision.

Important as this might be, it is quite different than the presumption contained in Section 113-B, applied in cases charged under the Dowry Death Act. Under the language of that section, once the prosecution has established the relevant facts predicate, the court "SHALL PRESUME" that the defendant had caused the victim's dowry death." Unlike the presumption contained in Section 113-A, this is a presumption of law. Under the terms of Indian Evidence Act Section 4 , the fact presumed must be regarded as proved, unless and until it is disproved.

Thus, presumptions of fact and presumptions of law have completely different effects on the allocation of burdens of proof. The Section 113-A presumption merely shifts the burden of going forward with evidence to the party against whom it is raised. The Section 113-B presumption, on the other hand, shifts the burden of persuasion. ${ }^{32}$ As we will later see, these two types of presumptions have very different purposes and effects, and represent fundamentally different judgments about the proper balance to strike between competing policy concerns.

30. See generally, M.C. Sarkar et al., 2 Sarkar's Law of Evidence, supra n. 22, $1502-04$.

31. Id. at 1509.

32. Syad Akbar v. State of Karnataka, AIR 1979 S.C. 1848 (1979 Cri. L. J. 1374). 


\section{Placing the Statutes in Context: General Principles Governing Burdens of Proof at Common Law}

The burden allocation provisions contained in the Protection of Civil Rights Act and the Dowry Prohibition (Amendment) Act represent dramatic departures from the ordinary principles governing burdens of proof under Indian law in particular, and under the common law more generally. In Indian law as in American, the burden of persuasion as to any particular fact generally rests on the party who wishes the Court to believe in the fact's existence. ${ }^{33}$ As provided in I.E.A. \$101, "[w]hoever desires any Court to give judgment as to any legal right or liability dependent on the existence of facts which he asserts, must prove that those facts exist." 34 Indeed, one of the illustrations given in $\$ 101$ states: " $A$ desires a Court to give judgment that $B$ shall be punished for a crime which $A$ says $B$ has committed. $A$ must prove that $B$ has committed the crime." ${ }^{35}$ No one would seriously dispute that in an action for homicide, one of the essential elements of the crime is that the accused caused the victim's death. Similarly, in an action to redress discrimination of the kind prohibited by the Protection of Civil Rights Act, no one would quarrel with the proposition that one essential element of the prosecution's case would ordinarily be that the victim's group status motivated the defendant's negative action against him.

Interestingly, one can point to a number of examples of transformative Indian law in which ordinary burden allocation principles have been overridden. So for example, in prosecutions for taking or demanding dowry under Sections 3 or 4 of the Dowry Prohibition Act of 1961, the defendant bears the burden of proving that he or she has NOT committed an offense under the Act. ${ }^{36}$

A second example is found in the Criminal Law (Amendment) Act of 1983, which amended India's criminal rape statute, Indian Penal Code \$376, and added a new \$114-A to the Indian Evidence Act. While in ordinary rape prosecutions the burden of proving absence of consent rests on the state, the new Indian Penal Code (I. P. C.) Section 376(2), combined with the new I. E. A. \$114-A provides a number of exceptions to this rule in cases where there exists an obvious power imbalance between the victim and the accused. Specifically, where the defendant in a rape prosecution is a police officer, a public servant, a manager of a jail, remand home, or hospital, or where the victim is pregnant at the time sexual intercourse occurs, the burden

33. Indian Evidence Act, $\$ 103$.

34. Indian Evidence Act, \$101. See generally, A.N. Saha, Law of Evidence 437-40 (1991).

35. Id.

36. This provision, codified as Section 8A of the Dowry Prohibition Act of 1961, was added to the statute through the Dowry Prohibition (Amendment) Act of 1986, 1986 A.I.R. 73 (Nag.) 189-90. 
of proving consent is placed on him, assuming of course that the prosecution is able to prove that intercourse occurred. ${ }^{37}$

A third example is found in the Protection of Civil Rights Act. Under $\$ 14$ of the Act, where a company is charged with committing an offense, including discrimination in employment against a member of a Scheduled Caste, any management employee of the company may be individually charged with violating the Act and, if charged, bears the burden of proving that the offense was committed without his knowledge or that he did everything reasonably possible to prevent the offense from being committed. ${ }^{38}$

In each of these instances, as under the Dowry Death Act or the Protection of Civil Rights Act, deviation from normal burden allocation principles is justified by Indian legal commentators on one or more of the following grounds. With respect to the Dowry Death Act, placing the burden of proof on the defendant is justified by the severe difficulties faced by prosecutors in adducing evidence of guilt. Because the crimes targeted by the Act generally occur in the privacy of the husband's home, and because family members are so frequently involved in the crime or unwilling to testify against their kin, placing the burden of proof on the prosecution rendered previous criminal statutes virtually useless in reckoning with dowry-related homicides. Given the practical realities of proof, a guilty family's silence under the previous regime virtually ensured its immunity to successful prosecution. As one leading Indian commentary observes in explaining the burden allocation provisions contained in the Dowry Death Act, "It is to meet cases where the proof of particular facts is not provable or easily provable that such presumptions are usually enacted." 39 The presumption of law imposed on the defendant forces

\section{I. E. A. §114-A provides:}

114-A. Presumption as to absence of consent in certain prosecuTIONS FOR RAPE. - In prosecutions for rape under clause (a) or clause (b) or clause (c) or clause (e) or clause (g) of subsection (2) of Section 376 of the Indian Penal Code (45 of 1860), where sexual intercourse by the accused is proved and the questions is whether it was with or without the consent of the woman alleged to have been raped and she states in her evidence before the Court that she did not consent, the Court shall presume that she did not consent.

38. Section 14 of the Protection of Civil Rights Act, as amended by the Untouchability (Offences) Amendment and Miscellaneous Provision Act, 1976 (No. 106 of 1976), provides in relevant part:

14. OfFEnCES BY Companies. - (1) If the person committing an offence under this Act is a company, every person who at the time the offence was committed was in charge of, and was responsible to, the company for the conduct of the business of the company, shall be deemed to be guilty of the offence and shall be liable to be proceeded against and punished accordingly:

Provided that nothing contained in this sub-section shall render any such person liable to any punishment, if he proves that the offence was committed without his knowledge or that he exercised all due diligence to prevent the commission of such offence.

39. V. Mohite \& V. Chavan, supra n. 17, at 197. 
the family to speak, to participate through the production of evidence as an active contributor to the court's search for truth.

Of course, this purpose could also be served by a presumption of fact. As we have seen, presumptions of fact operate precisely in this way: to force the party against whom the presumption is raised to speak. The use of a presumption of law then, as opposed to a mere presumption of fact, suggests the presence of additional policy interests at stake in the relevant burden allocation decision.

The first of these policy interests is implicated in virtually all of the statutes described above. Placing the burden of proof on a criminal defendant signals a legislative judgment as to the severity of the problem being targeted by the statute and the urgency of the need for radical social change. Placing the burden of proof as to consent on the defendant in a rape prosecution, or the burden of proof as to causation in an employment discrimination prosecution, or the burden of proof on the family in a case alleging the demanding or taking of a dowry, sends a clear symbolic message that the state means business. Whatever their practical impact on the outcome of prosecutions, burden of proof allocations have substantial symbolic and rhetorical value in law enforcement and related social justice discourse..$^{40}$

One aspect of this symbolic and rhetorical significance concerns the manner in which burden allocation decisions reflect implicit judicial or legislative judgments about "the common nature of things," or, more technically stated, about the prior probabilities associated with various classes of events. As various American commentators have described, the risk of non-persuasion is frequently placed upon the party seeking to establish the least likely scenario. ${ }^{41}$ This general principle is supported by two obvious policies. First, allocating the risk of non-persuasion to the party seeking to establish the leastlikely scenario minimizes the risk of producing an erroneous result. Requiring the party attempting, as McCormick put it, to "establish the improbable" accordingly seems more fair than assigning the risk of non-persuasion to his opponent, who as a matter of presumed base rate probabilities is prima facie more likely innocent than not.

Understood in this way, the rhetorical and political significance of burden allocation decisions becomes clear. An implicit judicial or legislative statement, reflected in a burden allocation rule, that negative action taken against a member of a subordinated social group is "more likely than not" attributable to some form of social oppression is profoundly political. Such a rule says much more than simply how

40. For an American commentary on the symbolic and rhetorical functions of burdens of proof, see, Richard H. Gaskins, Burdens of Proof in Modern Discourse (1992).

41. See, e.g., McCormick on Evidence \$337, at 950 (Edward W. Cleary ed., 3d ed. 1984); . Cleary, "Presuming and Pleading: An Essay on Juristic Immaturity," 12 Stan. L. Rev. 5, 13-14 (1959). See also, Hay, "Allocating the Burden of Proof," 72 Ind. L. J. 651,663 (examining the issue from a law and economics perspective). 
the evidence in any particular case should be evaluated. It implicitly validates the political claim that social injustice of the kind addressed by the relevant statute is still part of "the common nature of things" and continues to require resolute remedial action. Conversely, placing the burden of proof on the individual member of the subordinated group implicitly states, "Whatever your problem might be, it is not likely attributable to social injustice of the type addressed by the law you attempt to invoke.". Such a statement carries the implicit assertion that the oppressive conduct targeted by the statute is rare, and thus an unlikely explanation for the beneficiary group's continuing social, political, or economic misfortune. In this way as in others, burden allocation decisions express implicit judgments about the way things work in the world, and, accordingly, rhetorically advantage one segment of society over another. The advantage, of course, is practical as well. Where the evidence is ambiguous or unavailable, as it often is, burden allocation decisions permit one class of contestants to prevail over another simply by asserting, "I am right because you can not prove that I am wrong." 42

\section{Complexity and the "Common Nature of Things:" Lessons From the Dowry Death and Related Criminal Laws}

As we have seen, assigning the risk of non-persuasion to the defendant subtly reinforces a transformative law's legitimacy and, from both a rhetorical and a practical standpoint, advantages its proponents and beneficiaries. Accordingly, it can provide a useful tool for advancing the social and political goals underlying a transformative legal regime. But other concerns, in particular fairness to the defendant, must figure into burden allocation decisions as well. Fairness concerns are important in the design of any legal institution, but they loom even larger where a law imposes criminal sanctions. It is one thing to allocate a burden of persuasion to make a symbolic statement about the severity of a particular form of social injustice or the strength of the state's resolve to correct it. It is quite another to impose the very real practical consequences of that symbolic statement on a criminal defendant.

Implicit judicial concerns about the fairness implications of alternative burden allocation rules surface in a variety of ways. In exploring some of these, and in laying a foundation for comparisons between Indian and American burden shifting arrangements, it is instructive to contrast the nature of the presumptions, and their effects on burden allocations, contained in Sections 113-A and 113-B of the Indian Evidence Act.

\footnotetext{
42. Gaskins, supra n. 40 , at 2. Gaskins refers to this rhetorical device as the "argument from ignorance."
} 
As described above, ${ }^{43}$ Section 113-A, appears to establish a presumption of fact in abetment of suicide cases where the prosecution proves that prior to the suicide, the victim had been subjected to cruelty, defined either as harassment in connection with a demand for dowry, ${ }^{44}$ or as any willful conduct likely to drive the wife to commit suicide or to cause grave injury or danger to her life, limb or health. ${ }^{45}$ The presumption raised under Section 113-A does not necessarily shift the burden of persuasion; it necessarily shifts only the burden of going forward with evidence. ${ }^{46}$ Section $113-B$, on the other hand, applied in prosecutions under the Dowry Death Act, does automatically shift the burden of persuasion. Why automatically shift the burden of persuasion in the latter class of cases but make such a shift discretionary in the former?

One possible explanation, of course, is simply that the difference in burden allocations reflects political shifts in the Indian Parliament between 1983 and 1986. But a close reading of Section 113-A indicates that something more important to our present inquiry might account for the difference.

In most instances in which presumptions of fact are established in Indian statutes, the phrase "may presume" appears without modifiers. Section 113-A is phrased somewhat differently. It states that upon proof of the relevant facts predicate, a court in an abetment of suicide case "may presume, having regard to all the other circumstances of the case," that the victim's suicide was abetted by the defendant. This statutory "hedge" must reflect some concern that the fairness implications of differing burden allocation arrangements may, in abetment of suicide prosecutions, vary considerably from case to case.

Clues as to the precise nature of these concerns can be found in a 1987 decision of the Punjab/Haryana High Court in the case of Balbir Singh v. The State of Punjab. ${ }^{47}$ In Balbir Singh, the victim, a wife of three to four years, committed suicide by self-immolation. Approximately four months before her death, she had been beaten by her husband and her husband's mother, both of whom were charged with abetment of suicide under Indian Penal Code Section 306. Both were acquitted, and the original complainant (a relative of the victim) peti-

43. See text accompanying nn. 26-32, supra.

44. I.P.C. Section 498-A, subsection (b).

45. I.P.C. Section 498-A, subsection (a).

46. Under I.E.A. Section 113-A, a court has the discretion to shift the burden of persuasion to the defendant, which discretion is to be exercised "having regard to all other circumstances of the case." V. Mohite and V. Chavan, supra n. 17, at 195, 19899. In this way, the presumption established by Section 113-A represents something of a hybrid between the Indian presumption of fact and the presumption of law.

47. 1987 (1) Crimes 76. 
tioned the High Court for criminal revision. ${ }^{48}$ The petition, as directed against the husband, was based on the grounds that because he had been convicted of cruelty under 498-A in connection with the beating that preceded his wife's death, a presumption under Section 113-B should be drawn that he had abetted his wife's suicide.

In rejecting this argument, the High Court opined:

Any such presumption, if allowed to be drawn. . .would lead to utter chaos and disintegration of the very institution of matrimony. There is no gainsaying that with the ultimate aim of eradicating the evil of dowry, suitable legislation like the one noticed above has been enacted with a view to discourage this age old custom, but at the same time these salutary provisions cannot be allowed to be misused by the parents or relatives of a psychopath wife who may have chosen to end her life for reasons which may be many, other than that of cruelty. ${ }^{49}$

This discussion reflects two concerns, one about decision making under conditions of uncertainty and one about the potential abuse and unfairness inherent in the statutory scheme.

As we have seen, judicial presumptions are sometimes constructed to correspond to legislative or judicial judgments about the "common nature of things," or more technically stated, about the probabilities associated with varying classes of events or alternative explanatory theories. If a particular event is seen as having a number of relatively equally probable causes, the case for establishing a judicial presumption favoring one causal explanation over another is relatively weak. Such a case is much stronger in situations where the probabilities associated with one possible cause substantially dominate the alternatives.

As the Court's discussion in Balbir Singh reflects, suicide, in India as in the United States, is at least as closely associated and perhaps more closely associated with psychological imbalance on the part of the victim as with mala fides on the part of outside actors. On the whole, we (and I indicate here both Indian and American societies) have more ambivalent attitudes towards suicide victims than towards murder victims. The victim in a suicide case, by her own "deviant" action, has created a condition of causal uncertainty. We feel less comfortable, in the absence of individuating information, in presumptively attributing the act of taking one's own life to the causal agency of another person. One can easily see how a legislature

48. Criminal revision, under Indian law, is the functional equivalent of reversal on appeal. There being no double jeopardy prohibition under Indian law, a criminal defendant may be subject to conviction by way of criminal revision imposed by an appellate court.

49. Id. 
might feel more comfortable in establishing such a presumption in cases of apparent murder, including those suggesting "staged accident," than in cases involving suicide.

With regard to the relative susceptibility of Sections 113-A and $113-\mathrm{B}$ to abuse and unfairness, it is useful to compare the factual predicate required to raise the presumption in each. Under Section 113-B, the prosecution must prove, among other things, cruelty or harassment, not of any kind, but specifically in connection with a demand for dowry. The making of a demand for dowry must be proven by the prosecution beyond a reasonable doubt. Under Section 113-A on the other hand, to raise the presumption of abetment of suicide the prosecution must simply prove "cruelty," as that term is defined in I.P.C. Section 498-A. While one prong of this definition - that involving harassment in connection with demands for dowry - is relatively clear, the other is notoriously vague. ${ }^{50}$

Given the indeterminacy of the concept of "cruelty," the Indian legislature, like the Court in Balbir Singh, could easily have been concerned about the potential for oppression inherent in a strong presumption of abetment of suicide in non-dowry related situations. Members of the wife's family, distraught over the suicide and looking for someone besides the victim to blame, could too easily attempt to use ill-defined circumstances of domestic discord to hold a husband or members of his family criminally liable for the wife's death. In light of this possibility, the legislature could well have viewed the potential for abuse and unfairness associated with a strong presumption, especially when combined with the attributional ambiguity attending suicide, as too great.

Two general burden allocation principles, I suggest, can be seen operating here. The first harkens back to the notion that the risk of non-persuasion should correspond to "the common nature of things," best understood as an implicit assessment of the base rate probabilities associated with various classes of events. Section 113-A, I suggest, reflects the intuition that even if we could specify the base rate contribution of domestic "cruelty" in causing suicides, the relevance of that overall base rate in attributing the cause of a particular suicide would vary widely from case to case. Let us explore this point further.

Assume for a moment that the Indian Parliament based the burden allocation rule constructed by I.E.A. Section 113-B on the belief that, when an Indian woman dies of unnatural causes during the early years of her marriage, and where shortly before her death she was subjected to cruelty or harassment in connection with a demand for dowry, the odds that her husband or his family caused her death

50. For a thorough discussion of the contested meaning of "cruelty" under I.P.C. Section 498-A, see, V. Mohite and V. Chavan, supra n. 17, at 135-90. 
are greater than $50 \%$. What if one adds additional facts to the picture, in particular, the fact that the woman's death was by suicide? Does this additional fact change one's subjective assessment of the probability that the death is attributable to the causal agency of the husband or the husband's family? The court's opinion in Balbir Singh suggests that it might, depending on the precise nature of the additional facts. The assumed "common nature of things" connected with suicide appears different from, and somewhat more complex and situation-specific, than the "common nature of things" connected with other kinds of homicide.

In short, in many situations particularized facts may have a sufficiently significant impact on our subjective assessments of the relevant base rate probabilities that we feel uncomfortable setting a default burden allocation rule before such facts are specified. In such situations, the preferred course of action might be to invest courts with discretion to assign burdens of proof in accordance with the subjective probability assessments indicated by the relevant, case-specific facts.

A second principle, sometimes referred to as the "disfavored contention" or "disfavored party" rationale, might also be seen operating in I.E.A. \$113-A. This principle places the burden of persuasion on a party advancing a disfavored claim, or on a party who is him or herself disfavored as a consequence of prior, proven conduct connected with the events at issue in the case. ${ }^{51}$ Certain claims or defenses may be judicially disfavored, and this disfavor expressed by assigning the burden of persuasion on the issue to the party raising it. ${ }^{.2}$ In other situations, a party may be assigned the burden of persuasion because, through his own conduct, he has created juridical uncertainty on the relevant contested issue. In American law, the most celebrated illustration of this principle is the case of Summers $v$. Tice, ${ }^{53}$ in which the California Supreme Court shifted to the defendants the burden of persuasion on the issue of causation-in-fact, where both defendants had negligently fired rifle shots, one or the other of which had hit the plaintiff. A more modern version of the disfavored party principle can be found in a 1977 Title VII case, International

51. For a discussion of the operation of this principle in American evidence law, see, e.g., Edward W. Cleary, Presuming and Pleading, supra n. 41, at 11; Martinez, "Tax Collection and Populist Rhetoric: Shifting the Burden of Proof in Tax Cases," 39 Hastings L. J. 239, 252 (1988).

52. The treatment of contributory negligence frequently fits this description. See, e.g., Epstein, "Pleadings and Presumptions," 40 U. Chi. L. Rev. 556, 598 (1973)(Rule allocating burden of proving contributory negligence on the defendant demonstrates judicial disapproval of a legal principle which operates to excuse the defendant's own negligent conduct. This disapproval overrides more general principle that the burden of proving an issue should normally be placed on the party possessing more ready access to the relevant evidence.)

53. 199 P.2d 1 (Cal. 1948). 
Brotherhood of Teamsters $v$. United States, ${ }^{54}$ in which the United States Supreme Court shifted to the defendant the burden of persuasion on the issue of discriminatory intent in "Stage 2" individual relief proceedings, once the court had found that the defendant had discriminated against the plaintiff class as a whole. Having been shown to have violated the statute, the Court in effect determined that the defendant's denial of discrimination in any particular case should be viewed with disfavor, and the burden of persuasion assigned accordingly.

The difference between the presumptions raised under Indian Evidence Code Sections 113-A and 113-B can also be understood in light of this "disfavored party" principle. Where under Section 113-B, the prosecution has proven that the defendant had subjected the victim to cruelty or harassment for, or in connection with a demand for dowry, a mandatory presumption, shifting the burden of persuasion on the question of causation, is raised. By violating the Dowry Prohibition Act, the defendant has become, in effect, a disfavored party, justifying the imposition upon him or her of the risk of nonpersuasion.

In abetment of suicide prosecutions, whether the defendant should be treated as a disfavored party for burden allocation purposes is substantially more complicated. Recall that prosecutions for abetment of suicide can proceed absent a demand for dowry, so long as "cruelty," as defined in I.P.C. Section 498-A, subsection (a) is proven. Such "cruelty" has been interpreted to include treatment as widely divergent as baseless accusations of infidelity ${ }^{55}$ or inability to conceive a child, ${ }^{56}$ repeatedly coming home drunk late at night over the wife's persistent protests, ${ }^{57}$ and repeated beatings, verbal abuse, and withholding of food and access to her natal family by victim's husband and mother-in-law. 58 Conduct constituting cruelty may or may not be accompanied by demands for dowry. In other words, violations of I.P.C. 498-A may be associated with conduct justifying varying levels of moral opprobrium, and may be associated or disassociated with the practice of dowry.

Thus I suggest, where an abetment of suicide defendant has been guilty of "cruelty," as that term is defined in I.P.C. §498-A, but has made no demand for dowry, he or she is prima facie less disfavored

54. 431 U.S. 324 (1977).

55. See, e.g., Rishi Kumar v. State of Haryana, 1988(1) Cri. L.C. 378(Punjab and Haryana High Court).

56. See, e.g., Renu, et al. v. State of Haryana, 1990(3) Crimes 226.(Punjab and Haryana High Court).

57. Jagdesh Chander v. State of Haryana, 1988 Cri. L. J. 1048. But see, P. Bikshapathi v. State of Andhra Pradesh, 1989 Cri. L. J. 1186 (Andhra Pradesh High Court)(Daily consumption of liquor and coming home drunk not "per se" cruelty under Section 498-a).

58. Anjanabai v. State of Maharashtra, 1988 Mh. LJ. 641 (Bombay High Court). 
than would be the case had a demand for dowry been made. Whether a particular abetment of suicide defendant's conduct has been sufficiently opprobrious as to render him or her "disfavored" within the meaning of the disfavored party principle will depend on the particular facts and circumstances of any given case. One of these facts will be the presence or absence of a demand for dowry.

In summary, in abetment of suicide cases, individualized facts will influence judicial judgments regarding both the prior probabilities associated with competing causal theories and the normative standing of the defendant. Accordingly, in an abetment of suicide prosecution, I.E.A. Section 113-B gives the court discretion, having regard to all the other circumstances of the case, either to shift the burden of persuasion on the question of causation to the defendant, or to leave it with the prosecution, where it normally would rest.

In attempting to determine whether considerations such as these in fact animate judicial application of the presumption established by Section 113-A, it is useful to examine how the discretion that section provides is being exercised by the Indian Courts. In Samir v. State of West Bengal, ${ }^{59}$ the Calcutta High Court opined that in applying Section 113-A, a decision whether or not to shift the burden of persuasion to the defendant must ultimately turn on those factors which point to the existence of a causal nexus between the proven cruelty and the subsequent suicide. These factors include: the making and persistence of requests for dowry; whether those requests had been complied with or remained outstanding; the nature of the alleged cruelty; and the strength of the evidence establishing it. ${ }^{60}$

In addition to the factors considered in Samir v. State of West Bengal, the Court in Wazir Chand $v$. State of Haryana, ${ }^{61}$ also weighed the fact that, following the victim's lighting herself on fire, members of the husband's family failed to come to her aid. And, in State of Punjab v. Iqbal Singh, ${ }^{62}$ the Court also considered the temporal proximity between the victim's act in setting herself and her children on fire and the proven cruelty, which cruelty consisted of taunts, torture, beating, and demands for dowry. In all of these cases, both the disfavored party principle and the use of individualized facts to assess the relative prior probabilities of competing causal theories can be seen as influencing the exercise of judicial discretion under Section 113-A. Significantly, it is in those cases most directly implicating the goals of transformative dowry prohibition

59. (1991) 2 Crimes 867 (Calcutta High Court).

60. Accord, Shyama Devi v. State of West Bengal, 1987 Cri. L.J. 1163 (Calcutta High Court)(considering the making and persistence of requests for dowry, whether such requests were outstanding, and the nature and strength of proof of alleged cruelty).

61. AIR 1989 SC 378.

62. AIR 1991 SC 1532. 
laws that courts are most apt to shift the burden of persuasion to the defendant.

In summary, various Indian anti-subordination statutes, including but not limited to the Protection of Civil Rights Act, the Dowry Prohibition (Amendment) Act, and the Criminal Law (Second Amendment) Act, use evidentiary presumptions and burdens of proof to counter threats to transformative law posed by traditional normative systems. Strong presumptions of law, which shift the burden of persuasion, and weaker presumptions of fact which do not, perform different functions and reflect differing assessments of the relative policy costs and benefits associated with each. Before analyzing the nature and function of these allocation rules any further, let us explore the nature of presumptions and burdens of proof in the most frequently mobilized American civil rights law, Title VII of the Civil Rights Act of 1964 .

\section{Burdens of Proof in American Civil Rights Laws: The Case of Title VII}

The Civil Rights Act of $1964^{63}$ was passed at the height of the American civil rights movement of the 1950's and 1960's. While it addresses discrimination on the basis of sex, national origin, and religion as well as race, it was designed primarily to address the systematic social, political, and economic subordination of AfricanAmericans.

Parallels between the historic treatment of African-Americans and those designated as "Untouchables" in India can meaningfully be drawn. American Blacks suffered hundreds of years of chattel slavery, followed by over a hundred years more of legally and/or socially enforced segregation. Across the American South, American Blacks were subjected to formal civil disabilities including exclusion from the elective franchise and from public accommodations such as hotels, restaurants, transportation by common carrier, hospitals, and other business and service establishments. In the South by law, and in other parts of the United States by custom, Blacks were subjected to residential segregation, segregation into menial occupations, exclusion from state and private educational programs and large sectors of employment, as well as most licensed trades and professions. Among Whites, blackness was widely associated with what might best be understood as a secular version of ritual impurity. Throughout the United States, Whites tended to avoid close association with Blacks, except in situations where Blacks inhabited clearly defined, socially inferior roles. Until the 1950's intermarriage between members of different races was prohibited in many American states. Even

63. 42 U. S. C. $\$ 2000$ e, et seq., as amended. 
now, it continues to be socially stigmatized in many, if not all, parts of the country.

Even after civil disabilities imposed on African Americans were removed by Warren Court era interpretations of the post-Civil War Civil Rights Acts, those disabilities continued to be socially enforced in much the same way as in post-Constitution India, through private "self-help" involving social boycotts and violent reprisals.

The Civil Rights Act of 1964, like the Untouchability (Offences) Act of 1955, was enacted to redress the public and private enforcement of civil disabilities which a substantial segment of the population, at least in a majority of states in the American federation, had come to see as immoral. Like the UOA, the Civil Rights Act of 1964 is a federal law. Unlike the UOA, it provides a civil rather than criminal right of action. Aggrieved individuals, along with the federal government, have standing to sue in the federal district courts to enforce the Act's various provisions.

Title VII, the most frequently mobilized portion of the 1964 Act, prohibits and provides civil remedies for discrimination in employment based on race, color, sex, national origin, or religion. The Act covers employment or referral to employment by state and local governments, federal government agencies, unions, employment agencies, and private businesses employing 15 or more employees. In most suits under Title VII, a plaintiff must prove that the negative action taken against him resulted from intentional discrimination on a ground prohibited by the Act. ${ }^{64}$ This of course requires proof of a defendant's subjective state of mind, a task associated with substantial difficulty for both litigants and fact-finders. Given that employers rarely admit to discriminatory motives or leave paper trails from which an inference of discriminatory motive could easily be drawn, American courts have struggled since the early 1970's to construct a workable framework for the consideration and determination of this crucial element of liability in employment discrimination suits.

In an early case, McDonnell Douglas Corporation v. Green, ${ }^{65}$ the United States Supreme Court set out a three part analysis for the evaluation of what came to be known as an "individual disparate treatment" case. Under the McDonnell Douglas framework, a plaintiff must first establish a prima facie case. In the context of alleged

64. In a small subclass of Title VII cases, a plaintiff can prevail by showing that a facially neutral employment practice had a disproportionately negative impact on a group protected by the Act. One common misperception about Title VII is that a plaintiff can prevail in virtually any case by proving disparate impact. This is incorrect. Various legal requirements pertaining to the identification of a specific employment practice, and proof of a causal connection between that specific practice and a statistically significant disparate impact on the relevant applicant group have sharply narrowed the range of cases in which disparate impact theory can be used.

65. 411 U.S. 792 (1973). 
hiring discrimination, for example, a plaintiff does this by demonstrating:

(i) That (s)he is a member of a class protected by Title VII;

(ii) That (s)he applied for and was qualified for a position as to which the employer was seeking applicants;

(iii) That, despite his or her qualifications, (s)he was not hired; and

(iv) That the position remained open and the employer continued to seek applications from persons with comparable qualifications. ${ }^{66}$

The juridical function of this prima facie case, stated the Court on another occasion, was to "eliminate the most common nondiscriminatory reasons for the plaintiff's rejection," ${ }^{67}$ most notably, a failure to apply at a time when the employer had job openings available, or the applicant's failure to satisfy minimum qualification requirements.

After the plaintiff establishes a prima facie case, the burden shifts to the defendant to articulate one or more legitimate nondiscriminatory reasons for its decision. Assuming that the employer does so, and it usually does, the analysis proceeds to a third and final stage, in which the plaintiff has the opportunity to prove that the reason proffered by the defendant was not its real reason, but rather a pretext for invidious discrimination of a species prohibited by the Act. ${ }^{68}$

Following the Supreme Court's decision in McDonnell Douglas, the federal courts split on the question of whether the burden that shifted to the defendant at the second of these three stages was a burden of persuasion, analogous to the presumption of law raised under Section 113-B of the Indian Evidence Act in dowry death cases, or merely a burden of producing evidence, akin to the Indian presumption of fact. The conflict was resolved in 1981, when the Supreme Court decided Texas Department of Community Affairs $v$. Burdine. ${ }^{69}$

In Burdine, the Court held the burden that shifts to the defendant is not a burden of persuasion, but only a burden of coming forward with evidence. Assuming that the defendant satisfies this burden by proffering admissible evidence of a legitimate nondiscriminatory reason for the challenged decision, the presumption of discrimination raised by the prima facie case "drops from the case." In order to prevail, the plaintiff must prove that the employer's prof-

66. 411 U.S. at 802 (footnote omitted).

67. International Brotherhood of Teamsters v. United States, 431 U.S. 324, 358 \& n. $44(1977)$.

68. 411 U.S. $792,798$.

69. 450 U.S. 248 (1981). 
fered reason was a pretext for discrimination. Pretext, instructed the Court, could be proven "directly," by showing that some other reason (i.e., the plaintiff's race, sex, national origin, etc. . .) more likely motivated the decision, or "indirectly," by showing that the employer's proffered explanation was "unworthy of credence."70

In the years that followed Burdine, this latter method became the most common device by which Title VII plaintiffs proved discriminatory grounds based on circumstantial evidence alone. This was largely because, by the 1980's, few U.S. employers had official policies excluding women or minorities from particular classes of jobs, as had been the widespread practice when Title VII was first enacted. Similarly, by the 1980's, most people had learned, whatever their private attitudes might be, not to make statements indicative of racist, sexist, or otherwise prejudiced attitudes. "Direct evidence" of bias was rarely available to plaintiffs in employment discrimination cases.

Thus, with increasing frequency plaintiffs sought to prove pretext in the second manner prescribed in Burdine, by showing that the employer's proffered reasons were "unworthy of credence." In particular, plaintiffs would commonly seek to discredit the reason(s) offered by the defendant by showing that similarly situated employees who were not in the plaintiff's social group had been treated more favorably, or in discipline or termination cases less harshly, than the plaintiff had been treated. By discrediting the employer's stated reason in this way, plaintiffs hoped that the trier of fact would infer that the real reason for the employer's action was discrimination of a kind prohibited by the Act.

The logic underlying this "presumption of invidiousness" was most clearly articulated by the Supreme Court in the 1978 case of Furnco v. Waters, in which the Court opined:

[W]e know from our experience that more often than not people do not act in a totally arbitrary manner, without any underlying reasons, especially in a business setting. Thus, when all legitimate reasons for rejecting an applicant have been eliminated as possible reasons for the employer's actions, it is more likely than not the employer, whom we generally assume acts only with some reason, based his decision on an impermissible consideration such as race. ${ }^{71}$

As one can see from this excerpt, the indirect model of pretext proof rested on two implicit assumptions: 1) that, unless they are discriminating, employers are rational actors; and 2) that discrimination of the kind proscribed by Title VII, though subtle and largely covert, was still prevalent in American society. The presumption raised by plaintiff's proof of pretext thus reflected a particular understanding

70. 450 U.S. 248,255 n. 10.

71. 438 U.S. 567,577 (1978). 
of the "common nature of things," namely, an understanding that discrimination in the American labor market, while unlawful and covert, was still widespread.

Over the course of the 1980's, this belief about the "common nature of things," and in particular, the belief that discrimination remained widespread in American society, began to erode in both popular and judicial thought and discourse. The result, at least in the domain of Title VII disparate treatment litigation, was the development of yet another dispute over the nature and operation of the presumption raised by the Title VII individual treatment plaintiff's prima facie case.

The question at stake in what came to be known as the "pretext plus controversy"72 was this: in an individual disparate treatment case, what residual effect should the presumption raised by the prima facie case have in situations where the plaintiff proves that the reasons proffered by the defendant to explain its decision are "unworthy of belief?" In such situations, should the trier of fact, by virtue of the presumption raised by the prima facie case, be compelled, as a matter of law, to find for the plaintiff? Should the plaintiff, as a matter of law, be required to prove MORE than the elements of the prima facie case and the falsity of the defendant's proffered reason? Or, should the trier of fact simply be instructed to consider all the evidence, independent of the influence of any presumption, and determine whether the plaintiff has proven discrimination on the grounds of his or her group status by a preponderance of the evidence?73

In 1993, in St. Mary's Honor Center v. Hicks, ${ }^{74}$ a sharply divided U.S. Supreme Court chose the last of these three possible solutions to the pretext plus problem. Harkening back to its decision in Burdine, the Court held that once the defendant comes forward with evidence of a legitimate non-discriminatory reason for its action, the presumption raised by the prima facie case indeed "drops from the case." The presumption of discrimination so raised, once met by evidence of some legitimate non-discriminatory reason, has no remaining evidentiary significance. Simply stated, in an action for discrimination under Title VII, the burden of proof as to grounds remains at all times on the plaintiff, without regard, in the language of I.P.C. Section 113-A, to "all the other circumstances of the case."

72. See generally, Lanctot, "The Defendant Lies and the Plaintiff Loses: The Fallacy of the "Pretext Plus" Rule in Employment Discrimination Cases," 43 Hastings L. J. 57 (1991).

73. Curiously, no court suggested that in a case of this type, the burden of persuasion on the issue of intent should be shifted to the discredited defendant.

74. 113 S. Ct. 2742 (1993). 


\section{Interrogating Hicks: American \& Indian Law in Dialogue}

Although the American civil rights community decried the decision in Hicks as an extreme example of judicial activism on the part of a conservative, civil rights-hostile Court, one might reasonably argue that the holding was dictated by well-established principles of American evidence law. To understand how this might be the case, it is useful to reconsider the nature of judicial presumptions under Indian law, and then to contrast that framework with its American counterpart.

As described earlier, Section 4 of the Indian Evidence Code defines two different types of presumptions. The presumption of fact, signaled by the phrase "may presume," requires the party against whom it is raised to come forward with evidence, lest judgment be taken against it. While this presumption "requires a party to speak," and to a certain extent assigns the risks of factual indeterminacy in a manner different than it might otherwise be, it does not shift the burden of persuasion. The legal presumption, signaled by the language "shall presume" however, does operate to shift the burden of persuasion. This presumption can be raised even as to issues which would otherwise constitute an essential element of the plaintiff or prosecution's case in chief.

In the United States, federal evidence jurisprudence has no real counterpart to the Indian "presumption of law." Rule 301 of the Federal Rules of Evidence provides:

Presumptions in General in Civil Actions and ProceedINGS. - In all civil actions and proceedings not otherwise provided for by Act of Congress or by these rules, a presumption imposes on the party against whom it is directed the burden of going forward with evidence to rebut or meet the presumption, but it does not shift to such party the burden of proof in the sense of the risk of nonpersuasion, which remains throughout the trial upon the party on whom it was originally cast.

Rule 301, as adopted by the United States Congress in 1975, differs substantially from the version proposed by the Advisory Committee and approved by the Supreme Court. The Advisory Committee rule would have defined presumptions as shifting the burden of persuasion instead of just the burden of coming forward with evidence. In the language of the Indian Evidence Code, it was a "shall presume" rule, rather than a "may presume" rule. This was the approach advocated by Professor Morgan, in his debate with Professor Thayer over the proper function of presumptions in relation to the burden of proof.

In Rule 301, Congress adopted the "bursting bubble" approach advocated by Professor Thayer. Under this approach, applied by the Supreme Court in Burdine and again in Hicks, after a presumption is 
raised, and after the party against whom it is raised comes forward with admissible evidence to meet it, the presumption "bursts," and has no remaining evidentiary significance, although the evidence which gave rise to it remains in the case. The burden of persuasion remains where it always was, on the party on whom it was originally cast. Thus, the Federal Rules of Evidence provide no burden-shifting mechanism analogous to the Indian Evidence Act's Section 4 presumption of law, and, needless to say, no even more flexible tool such as that made available in abetment of suicide prosecutions by Section 113-A.

A literal reading of Rule 301 would suggest that only Congress, and never the courts, could re-allocate burdens of persuasion in federal civil or criminal actions. This however is not the case. The federal courts have on many occasions allocated burdens of persuasion in a manner consistent with perceived policy goals. In the absence of Congressional direction, the federal courts have made their own allocation decisions in First Amendment freedom of speech cases, ${ }^{75}$ Title VII disparate impact cases, ${ }^{76}$ admiralty cases, ${ }^{77}$ and, in certain situations, actions for breach of contract, ${ }^{78}$ to name but a few. In fact, in Price Waterhouse v. Hopkins, ${ }^{79}$ the U.S. Supreme Court held that once a Title VII plaintiff proves that her protected group status was a "motivating factor" in an employer's decision, the burden of persuasion on the issue of causation shifts to the defendant. Thus, literal readings of Rule 301 aside, the result reached in Hicks was perhaps not compelled by that Rule, but rather represents a subtle political choice between those competing policy interests always at stake in presumption and burden of proof allocation decisions.

The nature of those competing policy interests, and their relation to my earlier-posited distinction between normal, transformative, and captured law, can be illustrated by reference to the dispute over the soundness and significance of Hicks that developed in response to the decision's pronouncement in 1993. One group of legal commenta-

75. Mt. Healthy City Board of Education v. Doyle, 429 U.S. 274, 287 (1977)(allocating burden of proof to defendant in a "mixed motive" case brought by a tenured public school teacher alleging failure to rehire in retaliation for exercising First Amendment rights).

76. Griggs v. Duke Power Company, 401 U.S. 424 (1971)(placing burden of proof as to business necessity on the defendant in a disparate impact case).

77. Hood v. Knappton Corp., Inc. 986 F.2d 329, 331-332 ( $9^{\text {th }}$ Cir. 1993), citing, The Louisiana, 70 U.S. ( 3 Wall) 164 (1865)(allocating burden of proof to a drifting vessel in admiralty actions to further policy goal of avoiding maritime accidents); accord, James v. River Parishes Co., Inc. 686 F.2d 1129, 1133 (5 ${ }^{\text {th }}$ Cir. 1982).

78. E.g., United States v. New York, N.H. \& H. Ry., 355 U.S. 253, 256 n. 5 (1957) (availability of cars of the size ordered, where defendant had supplied cars of a different size); Nader v. Allegheny Airlines, Inc., 512 F.2d 527, 538 (D.C. Cir. 1975), rev'd on other grounds, 426 U. S. 290 (1976)(placing burden of proof on defendant to show that it did not breach its own rules in action involving over-booking of airline flights).

79. 450 U.S. 257 (1981). 
tors, best represented by Professor Deborah Calloway, ${ }^{80}$ argues that the decision in Hicks was not only wrong as a matter of law, but represents a fundamental retreat from an earlier judicial commitment to the struggle for civil rights. In other words Calloway argues, Hicks goes a long way toward making Title VII "captured" rather than "transformative" law.

According to this view, the indirect model of proof constructed in McDonnell Douglas and Burdine rested on an assumption that, absent some clearly articulated, non-discredited explanation, the adverse treatment of the groups protected by the 1964 Civil Rights Act more likely than not results from discrimination. According to Calloway, it is this "basic assumption" that the Court in Hicks rejects. In doing so she argues, the Court impliedly rejected the claim that discrimination continues to be "a vital part of contemporary American social and political life." ${ }^{11}$ Calloway therefore sees Hicks' disposition of the burden of proof problem there raised as invested with profound political and rhetorical significance. "[R]ejecting the basic assumption that unexplained adverse conduct towards women and minorities is the result of discrimination," states Calloway, "denies the continued existence of discrimination itself." 82

A second group of commentators, best represented by Professor Deborah Malamud, ${ }^{83}$ argues that Hicks was correctly decided and takes issues with the larger political claims made by commentators like Professor Calloway. Specifically, Professor Malamud contests Calloway's assertion that the burden of proof in discrimination cases should be allocated in accordance with beliefs about the prevalence of discrimination in society. Malamud argues that whether discrimination remains prevalent or not in no way determines whether a particular unexplained adverse action towards a particular woman or minority group member on a particular occasion can fairly be attributed to that cause.

But such is always the case, whenever burdens of proof are allocated in accordance with the base rate prior probabilities assumed to be associated with various explanatory theories or classes of events, or as the result of a deliberate decision to allocate to one rather than

80. Calloway, "St. Mary's Honor Center v. Hicks: Questioning the Basic Assumption," 26 Conn. L. J. 997 (1994). Other significant contributions to on this side of the debate include, Selmi, "Proving Intentional Discrimination: The Reality of Supreme Court Rhetoric," 86 Geo. L. J. 279 (1997); and Cunniff, "The Price of Equal Opportunity: The Efficiency of Title VII After Hicks," 45 Case W. Res. L. Rev. 507 (1995).

81. Selmi, supra n. 80 , at 284 .

82. Calloway, supra n. 80 , at 1036 .

83. Malamud, "The Last Minuet: Disparate Treatment After Hicks," 93 Mich. L. Rev. 2229 (1995). For another contribution coming to some of the same conclusions, but positioned substantially farther to the political right than Malamud, see Shuman, "The Politics of Presumption: St. Mary's Honor Center v. Hicks and the Burdens of Proof in Employment Discrimination Cases," 9 St. John's J. of Legal Commentary 67 (1993). 
another group of potential litigants the risks associated with factual indeterminacy. When used in this way, burdens of proof serve to assign the risk of non-persuasion to that group of potential litigants which, as a class, is either best-positioned to bear it, or which, according to our admittedly subjective assumptions about prior probabilities, will be wrongly denied judgment least often.

In essence, I would suggest, Malamud and Calloway are arguing over whether or not Title VII should still be viewed as "transformative law," or whether it is now more accurately characterized as "normal law," that is, law which seeks to enforce prevailing social norms against a small, deviant class of lawbreakers. If Title VII is properly seen as "normal law," than perhaps Professor Malamud is correct. But if it is still "transformative law," than Professor Calloway has the better argument.

Let us play this thought out a bit further, and connect it back to what we learned about burdens of proof and presumption in Indian anti-subordination law. Professor Calloway argues that courts adjudicating discrimination cases should enforce what she refers to as the "basic assumption" through the operation of something akin to an Indian presumption of law precisely because triers of fact in Title VII cases can not be counted on to agree with it. ${ }^{84}$ In essence, Calloway argues that, at least in cases in which the defendant's proffered reasons for a contested decision have been rejected as unworthy of belief, a mandatory presumption should be used to constrain the power of traditional norms to bias fact-finder inference and thereby frustrate the effective operation of the transformative legal regime.

In response, Malamud argues that, "deciding cases on the basis of a mandatory presumption that is inconsistent with contemporary beliefs about the nature of discrimination raises important questions about the legitimacy of the enterprise."85 But again, all transformative law functions in precisely this way. It will always eventually, if not immediately and continuously, be challenged, its legitimacy called into question by proponents of the old normative system. Malamud's argument against Calloway, at least in this narrow respect and if taken to its logical conclusion, represents an attack on the legitimacy of all transformative law, whether it be Title VII, the Untouchability Offences Act, the Dowry Prohibition Act, affirmative action programs promulgated by executive order, or ground breaking judicial decisions such as Brown v. Board of Education. ${ }^{86}$

84. See, Calloway, supra n. 80 , at 1008 .

85. Malamud, supra n. 83 , at 2260 .

86. 347 U.S. 483 (1954). In Brown v. Board of Education, the U.S. Supreme Court held that racial segregation in public education deprived African Americans of the equal protection of the laws guaranteed by the Fourteenth Amendment to the United States Constitution. In so doing, it rejected the "separate but equal" doctrine an- 
Perhaps in all contexts, but most particularly I would argue in the context of transformative law, one important function performed by presumptions and burdens of proof is precisely their capacity to constrain biases in fact-finder inference stemming from the subtle or blatant operation of the traditional normative regime. Legal adjudication necessarily requires fact finders to evaluate, draw inferences from, and choose between competing factual accounts. Where a member of a subordinated group seeks to enforce a law which diverges from traditional social norms, individuals implicitly or explicitly loyal to those traditional norms will tend to resolve factual ambiguities in ways that favor the defense and disfavor the prosecution.

The biases which give rise to this "prosecutorial disadvantage" need not be conscious or intentional. Stereotypes associated with members of subordinated social groups, other schematic expectancies as to the "common nature of things," subtle social biases in the assessment of witness credibility, all of these tend to "stack the deck" against the plaintiff or prosecution in cases involving transformative law. Allocating the risk of non-persuasion to the defendant in such cases may reset the balance of adjudication risk at a more appropriate level than that at which it might otherwise come to rest.

It can not reasonably be argued that evidentiary devices can never legitimately be used to constrain popular beliefs about "the common nature of things." Such a principle would necessarily require the abolition of many well-established principles of American and Indian evidence law, such as rules prohibiting the use of evidence of character or past acts in civil cases to prove action in conformity therewith. ${ }^{87}$ Accordingly, the question should be "when" and not "whether" it is appropriate to use burdens of proof of presumptions to counter popular assumptions about "the common nature of things."

Let us first consider the possibility that different considerations should drive policy making in this arena depending on whether we are dealing with normal or transformative law. It is reasonable to argue, at least as a starting point, that the burden of proof as to all elements of a case or claim should fall on that party - the plaintiff in a civil case and the prosecution in a criminal case - that makes a claim of mala fides against another person. Professor Dale Nance takes this position: in the absence of sufficient evidence adduced to show otherwise, one ought to presume that a person has acted in ac-

nounced in Plessy v. Ferguson, 163 U.S. 537 (1896 ), which doctrine had previously been used to justify state-enforced segregation in the American South.

87. Compare, Indian Evidence Act, $\$ 52$ with Federal Rules of Evidence, Rule 404(a). 
cordance with serious social obligations. ${ }^{88}$ This precept, which Nance refers to as "the principle of civility," is said to lie at the heart of liberal pluralistic community. Failing to presume that people will act in accordance with their legal obligations "denies them, in a sense, the dignity associated with their status as a full member of the community." 89

While Nance's principle of civility might be sound where normal law is concerned, I am skeptical about its wisdom - or even its logical validity - in cases involving transformative law. Nance's precept rests on the assumption that most people will act in accordance with established social norms. But what happens in situations involving normative instability, or situations in which formal legal norms diverge from local or traditional norms? What in that context does it mean for someone to behave "in accordance with serious social obligations?"

Transformative law deliberately seeks to displace a well-entrenched framework of "serious social obligations." People have different social reference groups, some of which may be loyal to the very social norms transformative law seeks to displace. People may derive their status as "full members of the community" more by meeting traditional normative expectations than by complying with transformative legal rules. As I suggested in the Introduction to this essay, rules designed with normal law in mind may work fundamentally different results where transformative law is concerned. In presumption or burden allocation decisions involving instances of transformative law, I suggest, Nance's "principle of civility" has little role to play.

To the contrary, where transformative law is concerned, the sensible "default setting" would more likely be to place the burden of persuasion on whatever party is most likely to be aligned with traditional social norms. Such an arrangement would be justified for variety of reasons.

Consider, for example, the problem of witness cooperation. As earlier described, transformative law can be thwarted where witnesses, because of social pressure, group alliances, or allegiance to the traditional normative system, refuse to provide the testimony needed to make successful mobilization of the new legal rules possible. This serious problem of witness non-cooperation is frequently cited to justify the legal presumption of culpability in dowry death cases under Section 113-B of the Indian Evidence Act. Placing the burden of proof on the defendant in such circumstances, while it does not protect against outright perjury, at least deprives the defendant

88. Nance, "Civility and Burdens of Proof," 17 Harv. J. of Law and Public Policy 647 (1994).

89. Id. at 653 . 
of Gaskin's argument from ignorance: "I am right because you can not prove that I am wrong."90

A second justification for this view derives from the rhetorical or symbolic purposes served by burdens of proof and presumptions. As Marc Galanter has observed, perhaps the most important feature of anti-subordination legislation like the Protection of Civil Rights Act is what he terms its "general symbolic output." 91 The acceptance or rejection of burden allocation rules, which express legislative or judicial adherence to one or another claim about "the way things are," necessarily privileges one world view over another, one group of prospective litigants over another, and one set of political priorities over another. As Gaskins suggests, burdens of proof and presumptions structure the parameters of discourse, and distribute in a political as well as in a legal sense the costs of uncertainty. ${ }^{92}$

Given the practical difficulties attending the mobilization of formal legal rights by members of subordinated groups, the tendency of popular normative systems to generate fact-finder bias, the exploitation of loopholes and other weaknesses in the law by judges loyal to the traditional regime, and the reluctance of witnesses to come forward in the face of potential boycotts and reprisals, there is little reason to treat transformative law and normal law the same where presumption or burden allocation decisions are concerned. The Indian experience makes plain what we who have grown accustomed to the American system may no longer be able to see: the allocation of burdens of proof and the construction of judicial presumptions are important tools through which proponents of transformative law may counteract the resistance inevitably mounted, in a host of subtle and not so subtle ways, by the traditional normative system it seeks to displace.

One important question left hanging, of course, is whether Title VII is normal law or transformative law. This is a complex, essentially empirical question, and its resolution lies largely outside the scope of this short essay. But I wish to suggest, at least with respect to the problem presented by Hicks, that insights provided by Indian law can help move the debate forward whatever the correct answer to this question might be.

Consider once more the distinction between the presumption of fact arising in abetment of suicide cases and the presumption of law arising in cases under the Dowry Death Act. As we earlier saw, the difference between the weaker, discretionary presumption applied in the first class of cases, and the relatively strong burden shifting presumption automatically raised in the second is justified on two

90. Gaskins, supra n. 40.

91. M. Galanter, Law and Society in Modern India, supra n. 1, at 218.

92. Gaskins, supra n. 40 . 
grounds. First, where suicide is concerned, a wider variety causes may more convincingly explain the act upon which the adjudication focuses than obtains in other prosecuted cases of apparent homicide. Second, in the case of suicide, the victim herself has, by her own action, created the uncertainty the burden of which the court must now assign to one or the other party. How might these two principles be applied to the problem of allocating the risks associated with factual indeterminacy in Title VII disparate treatment cases?

In bringing an individual disparate treatment claim under Title VII, the plaintiff contends that a particular employment decision was taken against him because of his social group status. The employer claims that the decision was taken for some legitimate, non-discriminatory reason, which reason, under Burdine, the employer is compelled to state. Professor Malamud is probably correct in maintaining that, subsequent Supreme Court dicta aside, the weak showing required to establish a prima facie case under McDonnellDouglas and Burdine does not in fact eliminate the most common reasons for the kinds of employment actions challenged in Title VII adjudications. Even after a plaintiff in a hiring case shows that he was minimally qualified for a position, or after a plaintiff in a termination case shows that she was performing a job for which she was qualified, there are many things besides discrimination which might explain the employer's decision. In short, I agree with Professor Malamud when she argues that the threshold established by the elements of the McDonnell-Douglas/Burdine prima facie case were never set sufficiently high to justify shifting the burden of persuasion to the defendant, assuming it did not belong there in the first place.

I would urge however that the policy balance shifts dramatically, in ways Professor Malamud fails to address, once a Title VII defendant's proffered non-discriminatory reason is disbelieved. Once the defendant has spoken, and once the trier of fact has judged his articulated reasons unworthy of belief, the individual disparate treatment defendant should be treated as a disfavored party, and the burden of persuasion on the question of discriminatory intent reassigned to him. Like the mixed motives defendant in Price Waterhouse, or the Stage 2 defendant in Teamsters $v$. United States, or like a defendant charged with dowry death under Sections 304-B of the Indian Penal Code, the defendant in a pretext plus case has, by his proffer of a false explanation, engaged in conduct which itself changes the balance of probabilities on the question of discriminatory intent. Under a "prior probabilities" approach to burden-shifting, there is good reason to reassign the burden of persuasion on the issue of intent to the defendant in such a case.

Furthermore, in a Hicks-type situation, the defendant's proffer of a false explanation for its actions has rendered the court's and the 
opposing party's search for truth substantially more difficult and has exposed the entire proceeding to a heightened risk of juridical error. There is no sound justification for imposing the cost of this obfuscation on the plaintiff. Nor is there any clear reason to apply Nance's principle of civility to a party whose testimony has been disbelieved.

At one point in her analysis, Professor Malamud states that, even after showing that the employer's proffered reason was not its real reason, the possibility that the trier of fact would reject the attribution to race was "a risk Hicks had to take."93 But if we are arguing about the proper allocation of burdens of persuasion, this assertion begs the cental question. Why, under the circumstances, should this be a risk that Hicks, and not the defendant, "has to take?" Where a defendant in a Title VII action has proffered a particular reason justifying its challenged decision, and the plaintiff has shown that reason to be pretextual, any remaining uncertainty as to the employer's real reasons is uncertainty of the employer's making. Why should that risk be assigned to the plaintiff, and not, as in the case of suicide under I. P. C. Section 113-B, to the party (or party's champion) whose action created the uncertainty in the first place?

Thus, even if we accept that Title VII is "normal law" in the sense that most negative employment actions taken against women and protected minorities are attributable to causes other than discrimination, it does not follow that, in cases where the defendant has created juridical uncertainty by proffering a false reason for its action, the risks attending that uncertainty should be imposed on the plaintiff. If we view Title VII as transformative rather than normal law, the case for assigning plaintiff the risk of nonpersuasion in such a case is weaker still.

Ultimately in my view, Hicks suggests that even with respect to litigation under a single statute, there may be some instances in which a Thayer-style bursting bubble presumption is warranted, and other instances in which a Morgan-style presumption does more of the necessary juridical work. But unlike the Indian Evidence Act, which makes both types of presumptions available to legislative or judicial decision makers, and in certain classes of cases, invests the court with discretion to tailor burden allocations to the particular facts of the case, the Federal Rules of Evidence provides for only one. Perhaps the Indian experience suggests that the Federal Rules of Evidence provide an inadequate set of tools for solving the particular problem illustrated by Hicks. As Professor Ronald Allen suggested in 1982, long before the pretext plus problem emerged, the univalent approach to evidentiary presumptions embodied in Rule 301 is inadequate to deal with the many and varied problems that burdens of

93. Malamud, supra n. 83 , at 2272 . 
proof and presumptions were designed to address. ${ }^{94}$ While the inference reasonably drawn from the elements of a plaintiff's prima facie case may in most cases be sufficiently weak as to justify only a Rule 301-style presumption akin to the Indian presumption of fact, such may not be the case after a plaintiff has also demonstrated the falsity of the defendant's supposedly legitimate non-discriminatory reasons. American evidence law, this observation suggests, provides only one tool where a second would be useful.

\section{Conclusion}

It is often said that the study of foreign legal systems has the salutary effect of freeing us from the blinders imposed by our own customs, presuppositions, and forms, exposing the contingency of our own legal order and illustrating the variety of available choices and frames. Unfortunately, that enterprise is often impeded by the degree of dissimilarity between different legal systems. Without a common core of concepts, procedures, tools, and terms, useful, as opposed to merely interesting, comparisons may be difficult to construct.

Because we share an English common law tradition, and a belief in the use of law as a vehicle for social change, and - on a more mundane level - because English is the working language of both our legal systems, American and Indian lawyers, judges, and legal scholars and civil rights activists have much we can learn from each other about alternative solutions to a common set of juridical problems. It is my earnest hope that this preliminary consideration exploring the nature and functions of presumptions and burdens of proof in American and Indian anti-subordination law, will serve to advance that emerging dialogue.

94. Allen, "Presumptions, Inferences and Burden of Proof in Federal Civil Actions-An Anatomy of Unnecessary Ambiguity and a Proposal for Reform," 72 Northwest U. L. Rev. 892 (1982). 